\title{
Chick growth and nutrient requirement during rearing period on eclectus parrot (Eclectus roratus, Müller 1776)
}

\author{
Rini Rachmatika*, Siti Nuramaliati Prijono, Andri Permata Sari and Suparno Suparno \\ Zoology Division, Research Center for Biology, Indonesian Institute of Sciences, Widyasatwaloka Building, \\ Jl. Raya Bogor KM. 46 Cibinong Science Center, Cibinong 16911, Indonesia
}

\begin{abstract}
Nutrition is an important aspect of the successful breeding of wild birds in captivity. This research aims to find out nestling growth of Eclectus parrot (Eclectus roratus, Müller 1776) by parentreared and nutrient requirement during rearing season. This research used a pair of Eclectus parrot with a male chick at first and fifth clutch, and female chick at the second, third, and fourth clutch. This research was conducted from July 2016 to June 2018. The bodyweight of chick was measured every week and feed intake was observed since the age of one week until the chick can eat independently. Feed was provided ad libitum and cafeteria. The chick was the altricial type. Feathers began to cover all bodies at weeks 9 . Fledging time was approximately at weeks 10-11. Chick could be separated from its parents at 20 weeks of age. Feed intake tends to be increased along with the increasing age of chick. Eclectus favorites feed is sunflower seed. Nutrient consumption when rearing male chick is more than rearing the female chick.
\end{abstract}

\section{Introduction}

Parrots are attractive birds to many people because of its colorful feather; hence these birds become one of the trading commodities. According to Anonimous [1], parrots are the first ranked in the export and import commodities of animal trades in the world since 19792008. Eclectus parrots (Eclectus roratus) evolved into ten subspecies that distributed in Indonesia as a whole in eastern Indonesia and also in Papua New Guinea and Australia [2]. Eclectus parrots are of least concern according to the IUCN Red List of Threatened Species [3]. BirdLife International [4] stated that the population of eclectus parrots is decreasing due to deforestation and loss of habitat. In fact, the bird population in the wild is decreasing due to poaching for illegal trade. More than $90 \%$ of the traded animals were caught from nature and not from captivity, with more than $20 \%$ die due to improper treatment [5]. Based on the information, captive breeding programs are important as one of the programs that support the conservation of eclectus parrot.

The sex of the eclectus parrot can be easily distinguished from the feather color. In general, male birds have a lighter color than females, which are often used to compete in getting females, but this does not apply for eclectus parrots. Females have very striking coat colors, namely red and purplish-blue, while male parrots are almost entirely green [6]. A small number of female parrots are more striking in color, and in most Corresponding author: rini007@lipi.go.id species, the difference is only in the slimness of body shape [7].

The feed is the most important component of animal husbandry aspects, including wild birds. The success of breeding cannot be separated from aspects of the feed provided, feed that must have occupied the nutritional needs of the bird. The composition of animal feed ensures their life continuity, whether it is feed only for survival, growth, or feed to stimulate the reproductive process. Nutrition needed is certainly related to the period at that time. The feed is given also determines the growth of the chick. The best bird chicks are chicks that hatch in their nests and are fed by their mothers [8]. This study aims to determine the growth of male and female chicks that are maintained by their parents, as well as nutrient requirements during the child-rearing period.

\section{Material and methods}

This study used a pair of parrots with five chicks in five breeding periods with one sample in each breeding period. In the first and fifth breeding periods, sex of chick was male; the second, third, and fourth clutch was a female chick. The study was conducted in bird captive breeding of the Research Center for Biology-LIPI. Birds were placed in cage measured $3.4 \mathrm{~m} \times 2 \mathrm{~m} \times 2.5 \mathrm{~m}$ equipped with nest, perches, bathing places, drinking places, and feed areas. The nest was measured $45 \mathrm{~cm} \mathrm{x}$ $30 \mathrm{~cm}$ x $45 \mathrm{~cm}$. Nest rounded entrances hole was having 
a diameter of $10 \mathrm{~cm}$. This research was run from July 2016 to June 2018. The observation of chick growth was carried out by weighing the chick every week, starting when the chick was one week of age, paired with visual observation. Meanwhile, the observation of feed consumption as family was carried out since the chick are hatched until they could eat independently. The feed consisted of fresh corn, guava, bean sprouts, kepok banana, coconut, sunflower seeds, carrots, water spinach, and long beans. Feed consumption was calculated by the amount of feed given minus the amount of feed remained. Feed and water were given ad libitum and cafeteria. Feed proximate analysis consisting of water, ash, ether extract, crude protein, and crude fiber was performed according to the Association of Analytical Chemists method (1995). The gross energy content of the feed was analyzed using an adiabatic bomb calorimeter (Parr Instrument 1266, Illinois, USA). Temperature and humidity data were recorded three times, which were in the morning (08:00 am, noon $(12: 00 \mathrm{pm})$, and afternoon (16:00 pm) every day. The data obtained were analyzed descriptively.

\section{Result and Discussion}

The average environment temperature in the cage during the study was $26.34 \pm 1.14^{\circ} \mathrm{C}$ (morning); $29.21 \pm 1.47^{\circ} \mathrm{C}$ (noon); and $29.08 \pm 1.64^{\circ} \mathrm{C}$ (afternoon). Humidity in the cage was $83.32 \pm 7.60 \%$ (morning); $68.09 \pm 9.72 \%$ (noon); $70.01 \pm 9.05 \%$ (afternoon). The temperature and humidity of the cage are abiotic factors that influence embryonic development during egg-laying by the female. The environment temperature and humidity can affect temperature and humidity of embryonic development. Cuttler and Abbot (1986) stated that incubating cockatiel eggs at a temperature of $37.5^{\circ} \mathrm{C}\left(99.5^{\circ} \mathrm{F}\right)$ and relative humidity of $56 \%$ produced the best results. Indeed, temperatures $1.4^{\circ} \mathrm{C}$ higher or lower than $37.5^{\circ} \mathrm{C}$ produced very poor hatchability and increased the incidence of abnormalities. The E. roratus produces 2-3 eggs. Females then incubate the eggs and rear the young [9]. Hatching day of E. roratus egg is 25-28 days. After that, the period of growth occurs until the chick completely covered in feathers for approximately 65 days. The growth of birds, in particular, depends on the food available. A graph of the weight of male and female chick in Figure 1.

Body mass increased rapidly to a mean peak mass of 400-450 g (Fig. 1). This value was reached at seven weeks of age for males and ten weeks of age for females. There was a delay in the growth of the bird occurring up to weeks 8 and 11 post-hatching. It may be caused by feather growth factors where the feathers begin to cover the entire body of the bird at week 8. Additionally, weight loss in week 11 was observed near the time of fledging in birds. This finding had a similar pattern to Petzinger et al. [10] that the Monk parrot experienced a rapid period of catch-up growth and continued to grow, leading to significantly higher peak body mass prior to fledging. Detail description of visual observation of chick growth is shown in Table 1.

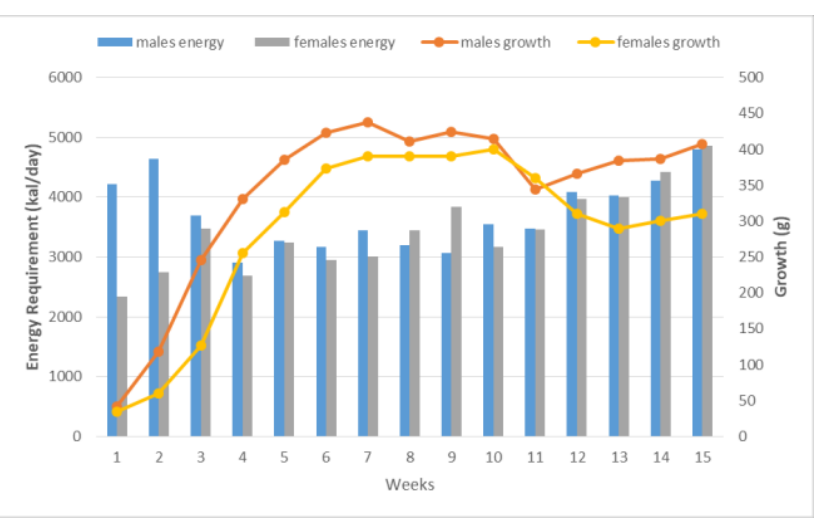

Fig. 1. Graph of chick weight male and female of eclectus parrot comparing with energy requirement

Energy requirement at growth period on males and females bird was shown in Figure 1. That graphic demonstrated the relation between growth rate and energy requirement on the growth period. During growth, energy is required both for maintenance functions and also for deposition of new tissue. The amount by which the total daily requirement exceeds the maintenance requirement depends upon the rate of tissue deposition and the composition of tissue deposited, and these vary with stage of growth and between species [11].

Based on data at Figure 1., males growth rate shown superiority compared with the females growth. Tendency for energy consumption in males and females is relatively the same. At the beginning of growth, males need more energy than females. Males exhibited higher potential for nutrient deposition than females, except for fat deposition [12]. This is in line with the data in Table 3. which shows that the highest consumption in males is corn and the highest consumption in females is sunflower seed which high fat contain.

The chick of E. roratus is included in the altricial type, which is born with closed eyes, the body is not covered by natal feathers (soft feathers at hatching), and in a weak condition, so it is very dependent on parental care until the chick can live independently. Based on field observation, fledging time for the chick is around weeks 10 to 11 .

Animals must have a predator risks at all life stages. At bird captivity, predation on eggs, nestling, and incubation period by snakes and small mammals is common and can be severe [13]. In parrot captivity, the predation came from snakes, small reptiles, small mammals like rats on eggs. Mortality in this stage, usually due to the abnormality of the chick. Abnormality of legs is common on the chick. Splay leg a possible genetic influence, developmental problems during incubation, inappropriate substrate that does not allow the bird to hold its legs in an anatomically correct position, dietary imbalance leading to nutritional secondary hyperparathyroidism with or without pathologic fractures, and slipped gastrocnemius tendons [14]. 
Table 1. Description of chick growth in captive breeding facility Research Center for Biology-LIPI

\begin{tabular}{|c|c|}
\hline Age (week) & Description \\
\hline 0 & Just hatched, do not have natal feather, reddish body, yellowish beak, eyelids are still closed \\
\hline 1 & $\begin{array}{l}\text { Eyes are still closed, the pin feathers have begun to appear in the spinal, humeral, and femoral parts, even } \\
\text { though they are still in the skin. In the abdomen has not been overgrown with feather pins. }\end{array}$ \\
\hline 2 & $\begin{array}{l}\text { Eyes begin to open. Gray-black fine hairs begin to cover the entire body. The beak has color changed to } \\
\text { black with the tip of the yellow beak }\end{array}$ \\
\hline 3 & $\begin{array}{l}\text { Soft feathers are getting longer, but the length is different; in the capital and ventral neck looks shorter } \\
\text { than other body parts. }\end{array}$ \\
\hline 4 & $\begin{array}{l}\text { The sheath has begun to appear on the alar precisely in the secondary feather, humeral, and capital. } \\
\text { Already seen a little bit of feather color that can determine male or female. }\end{array}$ \\
\hline 5 & $\begin{array}{l}\text { The primary feather sheath has begun to appear, and the secondary feather is getting longer. Feather } \\
\text { cover at the primary coverts and caudal starts to appear, while median coverts and greater coverts have } \\
\text { longer feather covers, and green feathers or red feathers have begun to appear. }\end{array}$ \\
\hline 6 & $\begin{array}{l}\text { Feathers have begun to cover the head, most of the wings, and sheath of the caudal feather is getting } \\
\text { longer, and green or red feathers are starting to appear. The back is still covered with natal feathers. }\end{array}$ \\
\hline 7 & $\begin{array}{l}\text { Feather has covered all parts of the wing except humeral parts, head and tail, the spinal part is still } \\
\text { covered with natal feathers }\end{array}$ \\
\hline 8 & Feather has covered most of the body except a little humeral part still covered natal feathers. \\
\hline 9 & The whole body has begun covered with the feather \\
\hline 10 & $\begin{array}{l}\text { The black color on the beak starts to disappear and becomes yellowish. Blue primary feathers have begun } \\
\text { to long; the chick has begun learning to fly. }\end{array}$ \\
\hline 11 & $\begin{array}{l}\text { Chick can fly by themselves, but sometimes falling. The offspring are always closed to the male parent, } \\
\text { and he is still doing allofeeding to their chick. }\end{array}$ \\
\hline 12 & Ventral feathers on the underside of the wing are still grayish black \\
\hline 15 & $\begin{array}{l}\text { Chick had actively flown by themselves and are still learning to eat, characterized by feeding themselves } \\
\text { after the male ate }\end{array}$ \\
\hline 20 & Chick can be separated from the parent \\
\hline
\end{tabular}

Table 2. Dry matter and nutritional content of feed on this research $(100 \% \mathrm{DM})$

\begin{tabular}{|c|c|c|c|c|c|c|c|}
\hline \multirow[t]{2}{*}{ Feed } & $\mathrm{DM}$ & Ash & $\mathrm{CP}$ & $\mathrm{EE}$ & $\mathrm{CF}$ & NFE & \multirow{2}{*}{$\frac{\mathrm{GE}}{\mathrm{kal} / \mathrm{g}}$} \\
\hline & \multicolumn{6}{|c|}{ - } & \\
\hline Fresh corn (Zea mays) & 32.50 & 3.85 & 16.14 & 10.00 & 2.40 & 67.61 & 4521 \\
\hline Guava (Psidium guajava) & 33.20 & 0.55 & 0.82 & 0.20 & 24.62 & 73.81 & 4426 \\
\hline Bean sprouts & 12.05 & 5.52 & 3.91 & 0.41 & 19.60 & 70.56 & 4963 \\
\hline Kepok Banana (Musa sp.) & 27.32 & 3.52 & 5.17 & 1.01 & 5.55 & 84.75 & 5133 \\
\hline Coconut (Cocos nucifera) & 58.40 & 2.73 & 3.57 & 32.18 & 11.75 & 49.77 & 6340 \\
\hline Sunflower seed & 96.35 & 4.39 & 29.91 & 49.64 & 5.94 & 10.12 & 8313 \\
\hline Commercial fruit based Pellet & 91.37 & 3.80 & 15.72 & 3.32 & 3.50 & 73.66 & 4353 \\
\hline Carrot (Daucus carota) & 24.67 & 8.92 & 10.21 & 0.20 & 1.09 & 79.58 & 3452 \\
\hline Water spinach (Ipomoea aquatica) & 14.10 & 11.70 & 33.63 & 0.44 & 1.10 & 53.13 & 4327 \\
\hline Longbean (Vigna unguiculata) & 37.63 & 6.47 & 2.93 & 1.05 & 1.76 & 87.79 & 4475 \\
\hline
\end{tabular}

$\mathrm{DM}=$ Dry Matter, $\mathrm{OM}=$ Organic Matter, $\mathrm{CP}=$ Crude Protein, $\mathrm{EE}=$ Extract Ether, $\mathrm{CF}=$ Crude Fiber, NFE $=$ Nitrogen Free Extract, $\mathrm{GE}=$ Gross Energy

The nutrient composition of feed during the experiment is presented in Table 2. As frugivorousgranivorous psittacine birds, $E$. roratus often feed on other dietary items, including fruits, seeds, and insects [15]. Sunflower seed contains high protein and fat used as a protein source as well as energy sources in the feed.
With longbean, sometimes birds only take its seed, especially young seed. Unripe seeds may also contain growth-related amino acids absent in mature fruits and seeds [16]. Meanwhile, kepok banana and corn used as energy sources. Feed consumption based on dry matter in eclectus parrot can be seen in Table 3. 
Table 3. Feed intake proportion based on dry matter of eclectus parrot on rearing period

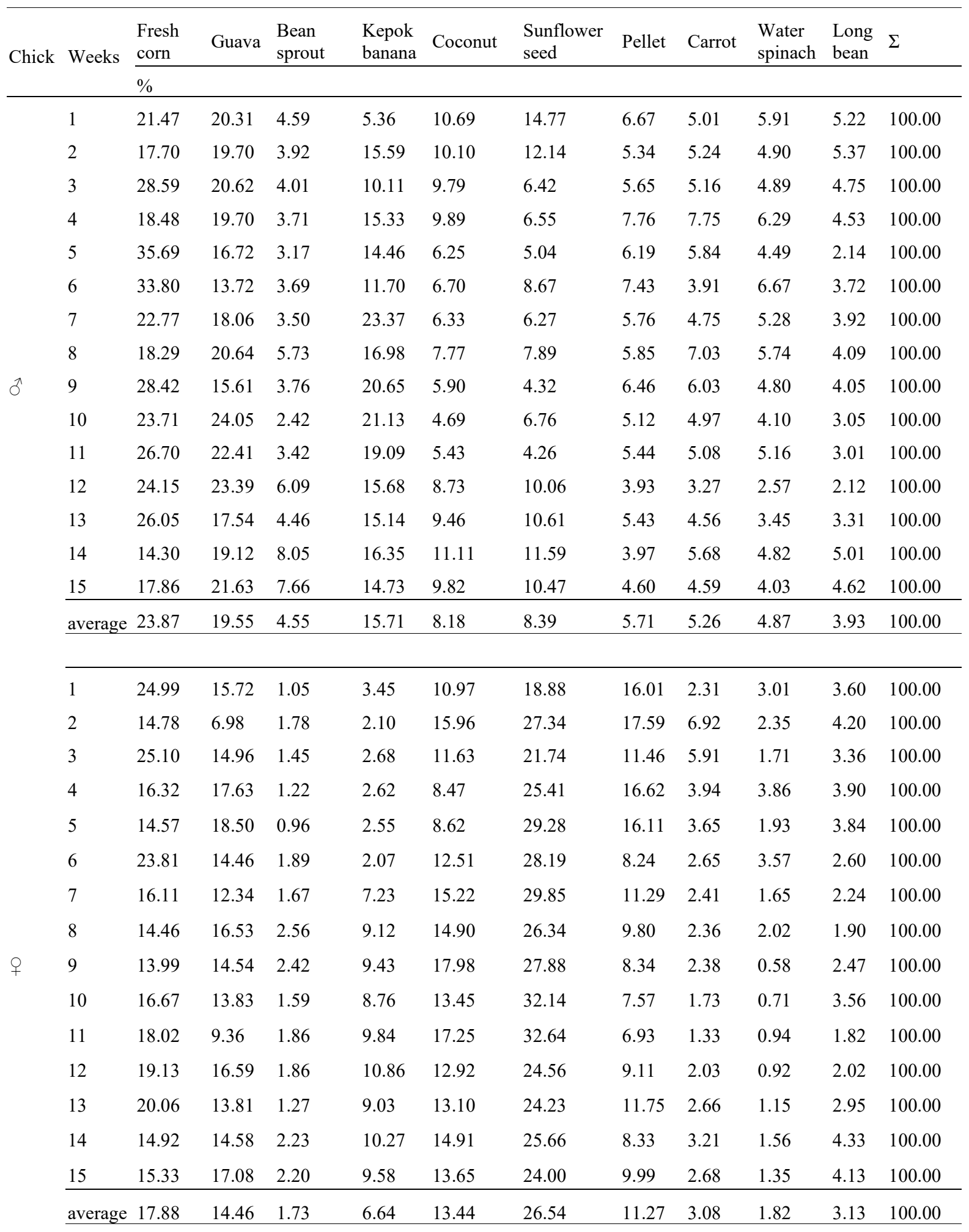

There were differences in feed intake proportion between male and female chick (Table 3). Male chick tended to consume fresh corn $(23.87 \%)$ rather than other feed components. On the other hand, the female chick consumed more sunflower seeds $(26.54 \%)$. Corn had a quite high content of nitrogen - free extract (NFE). NFE represent soluble carbohydrate of feed such as sugars and starches. Thus, NFE used as the source of energy. Male chick consumed high energy to improve early growth. However, the female chick did not show the same result. It was hypothesized that male chicks responded to increased dietary maternal energy due to heightened early growth rate [17]. 
Otherwise, Forbes and Shariatmadari [18] observed that males have higher growth potential and seem to be capable of responding by eating a high-protein food than females.

When provided ad libitum access to feed, birds generally eat an amount that satisfies their daily energy expenditure. Sari and Rachmatika [19] stated that birds might increase the feed intake when provided diets with lower than normal energy density (e.g., high-fiber foods) and, conversely, they may decrease the intake when presented a diet with high energy density (e.g., high-fat foods). Rachmatika and Sari [20] reported that feed protein levels might affect their digestibility.

Tabel 4. The average nutrient requirement of Eclectus parrot on the rearing period (\% DM)

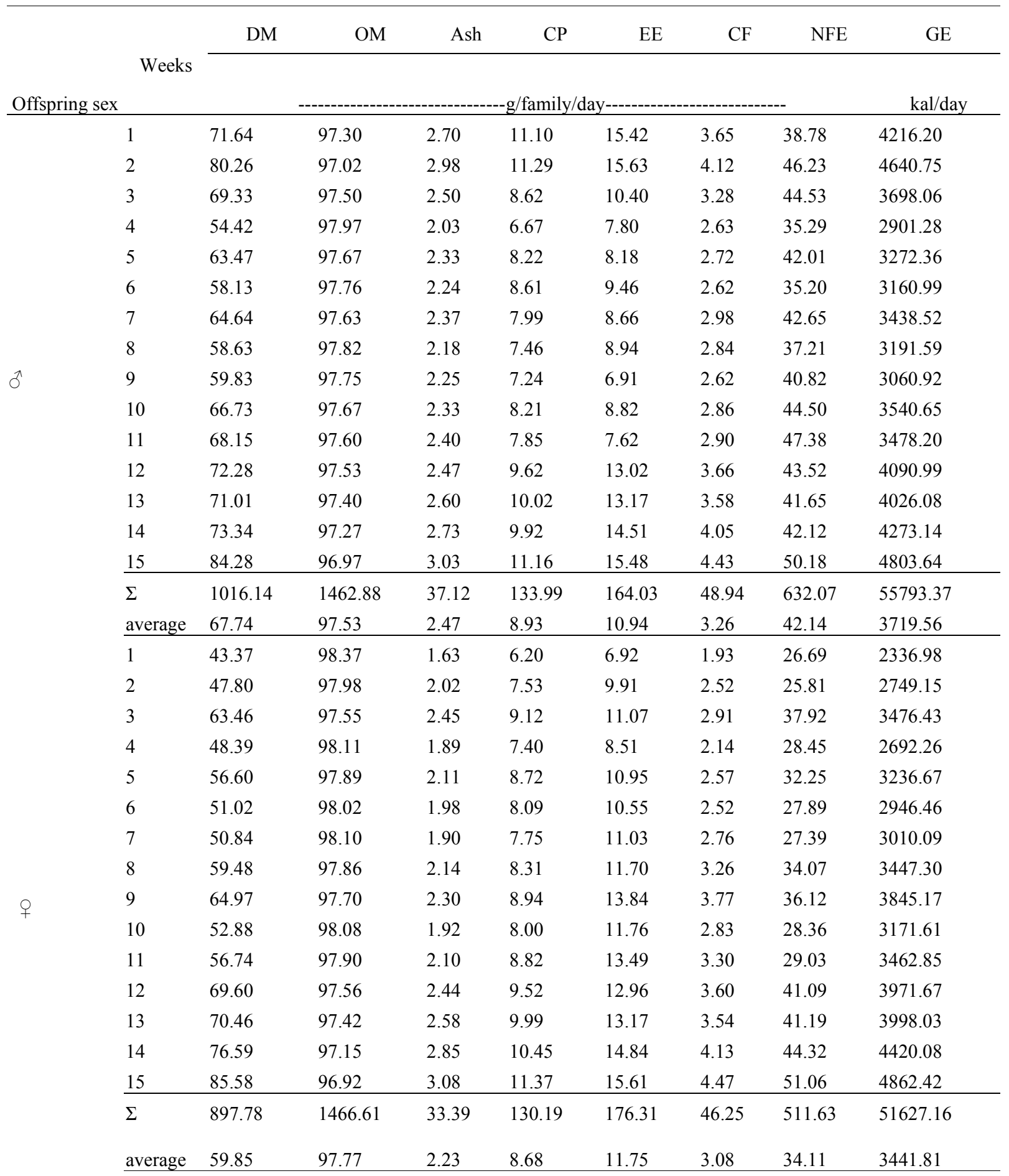

$\mathrm{DM}=$ Dry Matter, $\mathrm{OM}=$ Organic Matter, $\mathrm{CP}=$ Crude Protein, $\mathrm{EE}=$ Extract Ether, $\mathrm{CF}=$ Crude Fiber, NFE $=$ Ntrogen Free Extract, GE $=$ Gross Energy 
Prior to sexual maturity, the sexes have only small differences in their nutrient requirements, and males and females can usually be fed the same compromise diet to achieve acceptable growth rates (Table 4). The energy requirements for chick growth will be based upon the fractional growth rate of that species. Birds in the order Psittaciformes are among the slowest growing of altricial species and also develop endothermy at an earlier age. Thus, their energy requirements are likely to be more similar to precocial species than to highly altricial species, which grow faster and thermoregulate later [15].

In general, avian species unable to synthesize the essential amino acids. Furthermore, an essential level of protein must be included in the diet to meet the nitrogen requirements of the animal. The quantitative requirement for protein is dependent upon the physiological state of the bird, being lowest in adults at maintenance and highest in hatchlings and females laying large clutches of eggs [15]. The average protein requirement calculated in this experiment was $8.68 \mathrm{~g} /$ family/day for female and $8.93 \mathrm{~g} /$ family/day for male (Table 4). The protein requirement for growth of cockatiel chicks is $20 \%$ crude protein $(\mathrm{CP})(1.0 \%$ methionine 1 cysteine, $1.5 \%$ lysine, $14.64 \mathrm{MJ} \mathrm{ME} / \mathrm{kg}$ ) for maximal growth and survivability [21].

\section{Conclusion}

This research concluded that male chick has a higher growth rate than a female chick in the term of body weight. Feed intake on rearing male chick is higher than on rearing the female chick. The more significant feed intake proportion on male chick is fresh corn, while on female chick is sunflower seed. The nutrient requirements will increase along with chick growth.

We would like to thank the Research Center for Biology, Indonesian Institute of Sciences for financial support. We also thank Dr. Wartika Rosa Farida for her advice and support, Tri Hadi Handayani and R. Lia Rahadian Amalia, for helping with the proximate analysis of the feed. Thank to the Head of Zoology Division, Research Center for Biology LIPI, for the captive breeding facility.

\section{References}

1. Anonimous.

http://cites-dashboards.unep-wcmc.org/global?id=Birds [accesed on $29^{\text {th }}$ December 2010] (2010)

2. J.M. Forshaw \& W.T. Cooper, Parrots of The World. Third Edition (Landsdowne edition. Australia, 1989)

3. IUCN. www.iucnredlist.org [accesed on $29^{\text {th }}$ December 2010] (2010)

4. BirdLife. http://www.iucnredlist.org/details/22685022/0 [accesed on $23^{\text {th }}$ December 2016] (2012)

5. J. Handoyo, Siska, and Mastutiningsih, Komisi Nasional Plasma Nutfah, 6 (2005)

6. T. Arndt, Parrots: their life in the wild (Bromlitz, Horst Muller-Verlag Walsrode, 1986)

7. R. Heinsohn \& S. Legge, J Zool 259, 197-208 (2003) https://doi.org/10.1017/S0952836902003138
8. Anonimous. http://www.natural-pet-care.com [accesed on $4^{\text {th }}$ November 2011] (2011)

9. Burung Indonesia, Tatalaksana monitoring keragaman hayati partisipatif jenis-jenis burung kunci di kawasan Taman Nasional Manupeu Tanadaru, Sumba (Burung Indonesia, Sumba, 2007)

10. C. Petzinger, J.J. Heatley, J. Bauer, Vet Med-US 6, 321327 (2015) https://doi.org/10.2147/VMRR.S73804

11. J.K. Kirkwood. J Nutr 121(11), (1991) https://doi.org/10.1093/jn/121.suppl_11.S29

12. N.K. Sakomura, F.A. Longo, E.O. Oviedo-Rondon, C. Boa-Viagem, A.Ferraudo, Poultry Sci 84(9),1363-1369 (2005) https://doi.org/10.1093/ps/84.9.1363

13. J.W. Bradbury \& T.J.S. Balsby, Behav Ecol Sociobiol 70, 293-312 (2016) DOI 10.1007/s00265-016-2068-4

14. A.B. Worell, J Exot Pet Med 21, 115-123 (2012) https://doi.org/10.1053/j.jepm.2012.02.011

15. E.A. Koutsus, K. D. Matson and K. C. Klasing, J. Avian Med Surg 15(4), 257-275 (2001)

16. T.C.R. White, Biol Rev 86, 217-224 (2011) https://doi.org/10.1111/j.1469-185X.2010.00143.x

17. A. Chang, J. Halley and M. Silva, Anim Prod Sci 56 (2016) http://dx.doi.org/10.1071/AN15381

18. J.M. Forbes and F. Shariatmadari, World's Poultry Sci J 50, 7-24 (1994) https://doi.org/10.1079/WPS19940002

19. A.P. Sari \& R. Rachmatika, Jurnal Biologi Indonesia 10(1), 11-16 (2014)

20. R. Rachmatika \& A.P. Sari, Jurnal Biologi Indonesia 11(2), 253-258 (2014)

21. T.E. Roudybush \& C.R. Grau, J Nutr. 116, 552-559 (1986) https://doi.org/10.1093/jn/116.4.552 